\title{
Correction to: Virtual fracture clinic reduces patient X-ray volume for common wrist and ankle fractures
}

\author{
Conor S. O'Driscoll ${ }^{1}$ Andrew J. Hughes ${ }^{1} \cdot$ Fergus J. McCabe $^{1}$ - Elaine Hughes ${ }^{1} \cdot$ John F. Quinlan $^{1} \cdot$ Brendan J. O'Daly $^{1}$
}

Published online: 9 November 2021

(c) The Author(s), under exclusive licence to Royal Academy of Medicine in Ireland 2021

\section{Correction to: Irish Journal of Medical Science (2021) https://doi.org/10.1007/s11845-021-02812-y}

Originally, the article has been published online with an error in Table 2, under wrist injury, VFC mean $\mathrm{x}$ rays. " $(\mathrm{n}=$ " should read " $(\mathrm{n}=19)$ ".

The original article has been corrected.

Open Access This article is licensed under a Creative Commons Attribution 4.0 International License, which permits use, sharing, adaptation, distribution and reproduction in any medium or format, as long as you give appropriate credit to the original author(s) and the source, provide a link to the Creative Commons licence, and indicate if changes were made. The images or other third party material in this article are included in the article's Creative Commons licence, unless indicated otherwise in a credit line to the material. If material is not included in the article's Creative Commons licence and your intended use is not permitted by statutory regulation or exceeds the permitted use, you will need to obtain permission directly from the copyright holder. To view a copy of this licence, visit http://creativecommons.org/ licenses/by/4.0\%.

Publisher's Note Springer Nature remains neutral with regard to jurisdictional claims in published maps and institutional affiliations.

The original article can be found online at https://doi.org/10.1007/ s11845-021-02812-y.

Conor S. O'Driscoll

coodrisc@tcd.ie

1 Department of Orthopaedics, Tallaght University Hospital, Dublin 24, Ireland 